\title{
An Assessment of Covid-19 Pandemic Impact on Indonesian Tourism Sector
}

\begin{abstract}
Muhammad Eko Atmojo ${ }^{1}$, Helen Dian Fridayani ${ }^{2}$
${ }^{1}$ Department of Government Science, Universitas Muhammadiyah Yogyakarta, Indonesia

${ }^{2}$ Gradute Institute of Political Economy, Department of Political Science, National Cheng Kung University, Taiwan ${ }^{1}$ Corresponding Author: muhammadekoatmojo05@gmail.com

doi) http://dx.doi.org/10.18196/jgpp.811338

Article Info:

Abstract: This paper aims to analyze the impact of the COVID-19 outbreak tourism sector. The pandemic has a tremendous impact on all countries, including Indonesia, and many sectors are affected, including tourism. The most affected is the micro, medium-small enterprise or called MSME sector. It has a significant influence on the country's economic growth. The pandemic has caused the tourism small and medium-sized enterprises to experience huge losses as no foreign tourists will come. The method used in the research was content analysis which analyzed new media that show the topic related to COVID-19 and tourism. In contrast to previous studies, the

Article History;

Received:

2020-09-12

Revised:

2021-01-20

Accepted:

2021-02-02 and costs. This study tries to look at how the COVID-19 pandemic has a severe impact on the tourism sector. As a result, the number of foreign tourist visits or foreign tourists to Indonesia decreased in 2020 by $28.85 \%$ compared to the number of visits in 2019 . Some areas, such as Bali and Yogyakarta, have lost both local and foreign tourists. This situation has affected MSME providers of travel, hotels, souvenir providers, regional handicrafts, and food and beverage providers in tourist areas.
\end{abstract}

Keyword: COVID-19; Tourism; Economy.

\section{INTRODUCTION}

Since the COVID-19 pandemic, many countries have taken rapid action to protect the public and its economy. The COVID-19 pandemic has crippled the world economy. The hospitality industry has been facing one of the darkest times in 2020 (Smart, Ma, Qu, \& Ding, 2021). Many countries have taken one step towards closing flights to and from China. Steps have been taken to shield the countries from COVID-19, but so many countries worldwide have been exposed to COVID-19 incidents. As a precaution, governments worldwide responded with stringent interventions that within days shut down tourism worldwide (Kaczmarek, Perez, Demir, \& Zaremba, 2021). The situation was unprecedented, and perhaps no other sector was hit as hard by COVID-19 as tourism and leisure and one of them is Indonesia. As a developing country, Indonesia still depends heavily on other countries' roles, especially in terms of the need for raw materials such as plastics, textiles, and others (Mustaqim, 2020). Indonesia is one of the COVID-19 affected nations, where the case was first declared on March 2, 2020. In Indonesia, many sectors have been affected since the first case to date. The sectors affected by the COVID19 case in Indonesia are the economic sector, the tourism sector, the taxation sector, the trade sector, the industrial sector, oil and gas, and the micro, small and medium-sized enterprise (MSME) sector (Katz, 2020). Of course, many sectors are the key pillars of economic development in Indonesia, including the tourism and the MSME sectors.

The ban on flights to foreign countries, notably China, will significantly impact Indonesia because Indonesia's tourism market share comes from China, where many foreign Chinese tourists enter Indonesia for a holiday. Data from the Central Statistics Agency (BPS) shows that in 2019 tourists from China reached 2,07 million, which accounted for 12.8 percent of total foreign tourists in 2019 (Hanoatubun, 2020). This coronavirus's existence is many domestic and foreign 
tourists who delay their activities to visit other countries. The tourism sector is always alongside the MSME sector in its journey, particularly in tourist souvenir providers for domestic and foreign tourists alike.

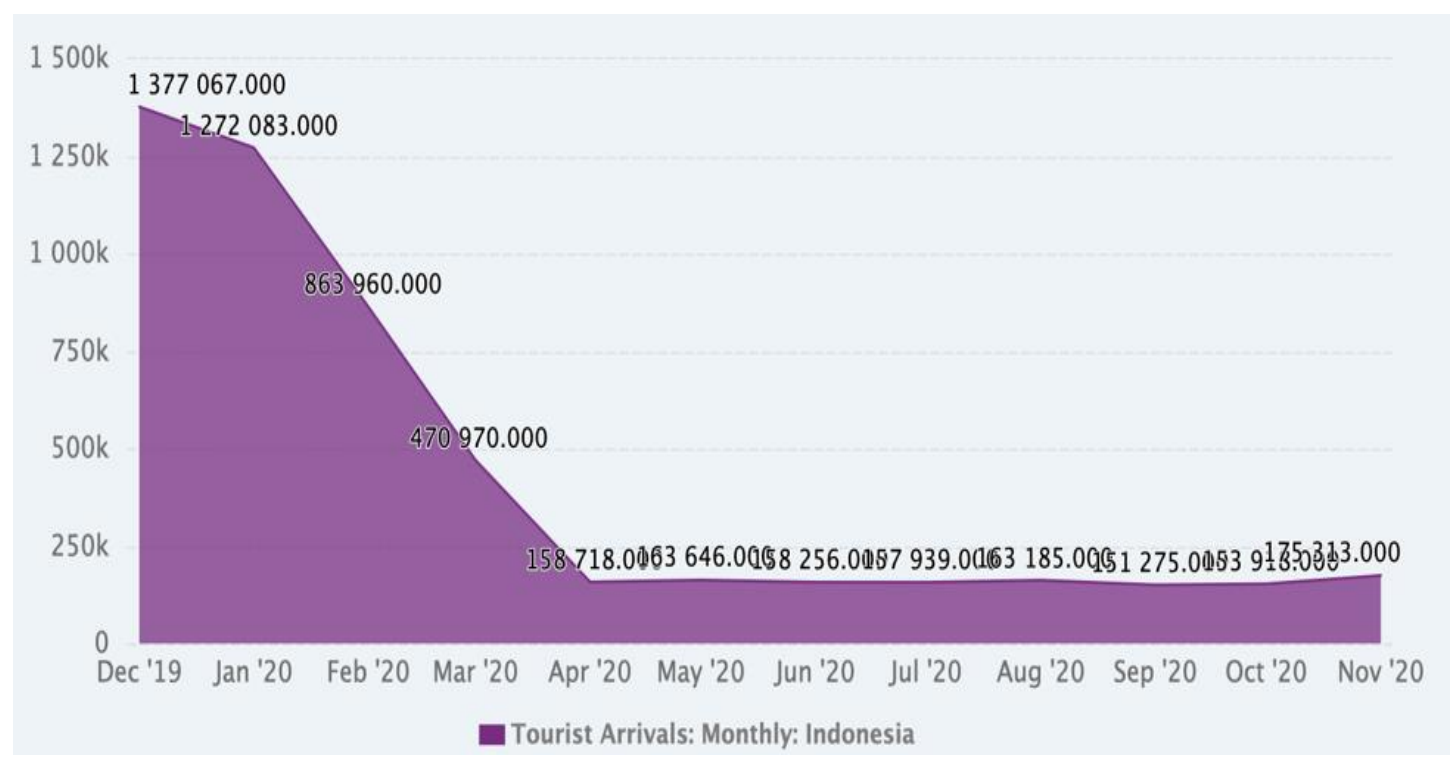

Figure 1. Tourist Arrivals in Indonesia Dec 2019- Nov 2020.

Source: Indonesian Global Economic Data, Indicators, Charts, 2020.

Figure 1. explains that Indonesia Guest Entries recorded 175,313 individuals in November 2020, compared with 153,918 visitors within the past month. Indonesia Guest Entries information is overhauled month to month, accessible from Jan 1979 to Nov 2020. The information came to an all-time tall of 1,547,231 visitors in Jul 2018 and a record moo of 36,730 individuals in January 1979. The Central Bureau of Insights gives month-to-month Traveler Entries. Visitor Entries incorporate Same-Day Guests. It is already apparent based on those graphs that the tourism sector has a severe impact. Global visitors started experiencing a dramatic decline by 2020 because of the pandemic. The decline in the number of tourists will affect the MSME sector, specifically the tourism sector, bearing in mind that these two sectors play a vital role in its economic growth. Moveover, the situation also has had an impact on the transportation industry. For instance, at the beginning of March, 735 international flights were cancelled, although the domestic flights were not affected (Gandasari \& Dwidienawati, 2020). Korean Air stopped offering its services, and over 1,100 flights were affected by the coronavirus in March (Soehardi \& Untari, 2020).

The areas with potential for tourism like Yogyakarta, Malang, Bali, Lombok, and others need many MSMEs. This condition has become one of the government's concerns in reviving the community economy of the people. MSMEs are always sided with the tourism sector because these two sectors are essential pillars or contributors to Indonesia's economic growth. One of them can be seen from MSMEs' contribution to national economic growth, as seen from their contribution to Indonesia's annually-increasing Gross Domestic Product (GDP) (Rifa, 2013). Moreover, MSME is also one of the sectors that play a vital role in Indonesia's labor absorbance. The MSME sector dominated business units in Indonesia based on Bank Indonesia data in 2016, and the micro-enterprise absorbed a lot of labor (Hanoatubun, 2020). MSMEs thus became one of the sectors which felt the impact in the pandemic COVID-19 era. It is likely that because of the COVID-19 virus, many MSMEs start laying off their employees.

To respond to the potential spread of COVID-19 in the Indonesia area, a significant action was released by the Indonesia government, provincial, regencies, and cities. Some offices, universities, and schools in areas with positive COVID-19 cases were closed (Hakim, 2021). Furthermore, MSMEs' effect in regions adopting large-scale social restriction policies is also 
quite significant because MSME actors get restrictions from the security apparatus, as in DKI Jakarta. The security forces will conduct forced closure based on the DKI Jakarta PSBB (Indonesia large-scale social restrictions) regulations in Governor Regulation Number 33 of 2020 (Said, 2020). This regulation will affect small and medium-sized enterprises, given that MSMEs in Indonesia still have a variety of problems that arise, including the lack of money, the difficulty of marketing access to MSME goods, restricted human resources, the still-low quality of human resources, and low-quality technology (Rukmana \& Sukanta, 2020). Therefore, the government must adopt a policy to save MSMEs during the COVID-19 pandemic period, both in the economic and tourism sectors

Indeed, the existence of COVID-19 makes the pace of economic growth in Indonesia continue to decline because both sectors with a large share of economic growth in the country are very seriously affected. The drop in the number of tourists coming to Indonesia is one explanation for international tourists and domestic tourists due to the Indonesian people's reluctance to travel and worry about the effects of COVID-19 (Sugihamretha, 2020). The decline in tourism, travel, and business will also impact the MSME market and increase Indonesia's unemployment. Besides the MSME sector, the tourism sector has a role in employment that is quite large. Based on the argument from (Sugihamretha 2020), tourism sector jobs are laborintensive, absorbing about 13 million employees. It is undoubtedly a significant loss for Indonesia, owing to the rising unemployment rate and the falling amount of the country's economy. Besides, the buying power of citizens will also diminish due to the COVID-19 pandemic that hit Indonesia.

This pandemic's presence will severely impact Indonesia, especially in the economic sphere, due to a substantial decline in its economic revenue. The MSME sector and tourism already dominate economic development in Indonesia (Isyunanda, 2020). The decrease in economic growth rate was due to the declining number of tourists arriving in Indonesia, which also affected the MSME market. Besides the command pandemic rate of economic growth, this situation also affects increasing the number of unemployed in Indonesia because MSMEs and the tourism industry play a significant role in absorbing labor. Centered on (Hardilawati's, 2020) comments that Indonesia's MSMEs are recruiting 116,978,631 jobs. However, about 13 million jobs are absorbed into the tourism sector (Sugihamretha 2020).

Based on these results, there is a dual position for the MSME and tourism sectors, including rising economic growth, and the second reduces unemployment. MSME and tourism are an option for rising unemployment. These two sectors will suffer huge losses with this pandemic. Bearing in mind these two sectors are leading sectors in improving the economy of the country. Tourism plays a crucial role in many countries' development (Moreno-Luna, Robina-Ramírez, Sánchez, \& Castro-Serrano, 2021). The dependence on tourism, which represents $12 \%$ of the economy's GDP, makes it the third most vulnerable destination in the world, in comparison to the rest of the tourism leading countries (Chakraborty \& Maity, 2020).

The tourism sector contributes to the foreign exchange of the country almost every year. With this pandemic, each country depending on the tourism sector will suffer losses due to a decline in foreign exchange. One is Indonesia, where it is projected that Indonesia will lose 350 million USD of foreign exchange with the COVID-19 pandemic (Mahadiansar \& Aspariyana, 2020) due to a fall in the number of foreign tourists who come to Indonesia. Besides losing foreign exchange, other tourism-related sectors, such as MSMEs and others, will also suffer significant losses. In contrast to previous studies, the decline in the number of tourists was due to the reach of tourist attractions, facilities, access, and costs. This study tries to look at how the COVID-19 pandemic has a severe impact on the tourism sector. Therefore, this study provides a new perspective towards the tourism sector with the different challenges: the COVID-19 pandemic. This paper can contribute pragmatically to determining tourism policy during a pandemic and after a pandemic. In theory, this paper contributes to new science in tourism, especially MSMEs and the policies. 


\section{RESEARCH METHOD}

The method of analysis used in this study was literature. The researchers did not go directly to the literature method field but instead looked for secondary data as a reference text. At the same time, qualitative is the type of research used. Salim notes that qualitative study has the following characteristics: (1) research data are obtained directly from the field, not from a controlled laboratory or research; (2) data mining is naturally done. It visits the natural situations of the subject, and (3) researchers must develop dialogical situations as scientific situations to obtain new meaning in categories of responses (Salim, 2006). The implementation of this research would consider the impact of the COVID-19 pandemic in tourism in Indonesia on the MSME industry. To see the extent of the impacts of COVID-19 on MSME actors in tourism in Indonesia, this issue, therefore, needed to be examined.

\section{RESULT AND DISCUSSION}

The tourism sector is one of the sectors most affected by the coronavirus (COVID-19). The impact was revealed from data from the World Travel and Tourism Council. The latest research report of the world travel and tourism council (WTTC) lists up to 75 million workers at immediate job risk as a result of COVID-19 (Škare, Soriano, \& Porada-Rochoń, 2021). In Indonesia, the virus's spread hits the tourism industry seen from the decline of tourists who came to visit since January 2020. The tourism sector suffered a loss of 1.5 billion US dollars. The total amount of the loss was dominated by the number of tourists from China (Hong et al., 2020).

Indonesia, which is dominated by the existence of Micro, Small and Medium Enterprises (MSMEs) as the backbone of the national economy, is also seriously affected not only in the aspects of total production and trade value but also in the number of workers who have lost their jobs due to this pandemic. Data from the Ministry of Cooperatives and Small and Medium Enterprises showed that in 2018 there were 64,194,057 MSMEs in Indonesia (or around 99 percent of the total business units) and employed 116,978,631 workers (or around 97 percent) of the total labor in the economic sector) impact for MSMEs (Alimuddin, 2020).

The tourism sector has been the mainstay of the government as the source of Indonesia's second-largest contribution. However, the COVID-19 pandemic has changed everything. No one can survive because no travelers are visiting this archipelago. The tourism business has nearly collapsed since the World Health Organization (WHO) established the global COVID-19 pandemic (WHO, 2020). Since the government's instruction to carry out physical distancing and to keep moving at home to break the chain of distribution of COVID-19, the tourism sector has begun to slow down and even almost collapsed.

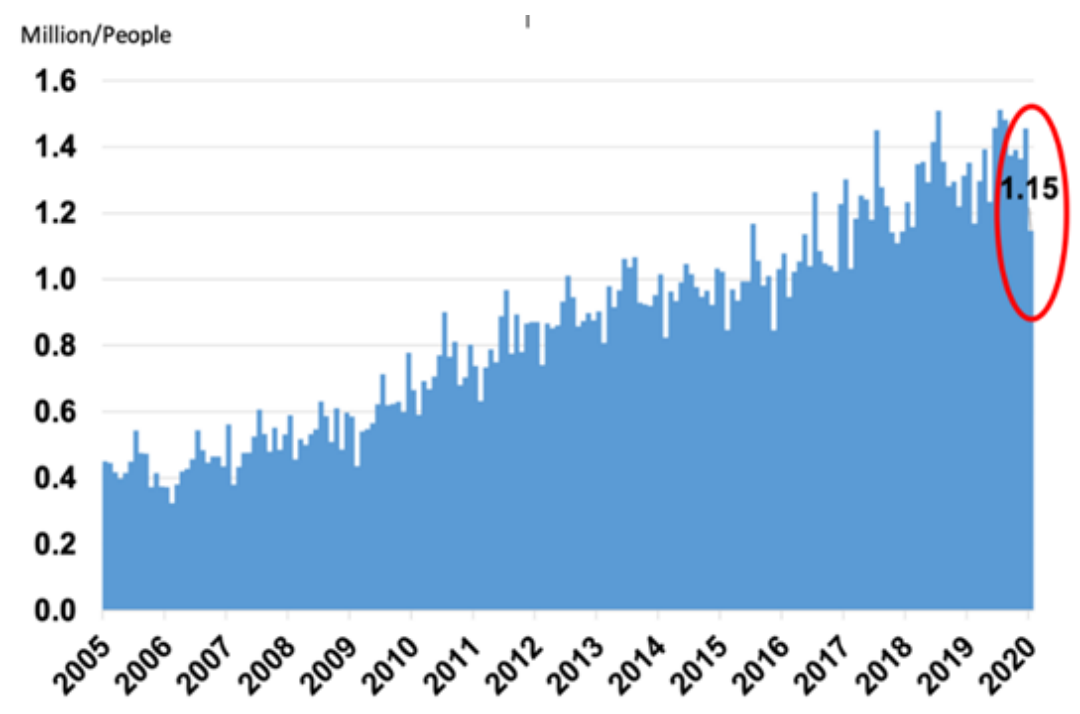

Figure 2. The Arrival of International Aircraft Passengers Down Sharp Source: Global Economic Data, Indicators, Charts \& Forecasts, 2020. 
Figure 2. shows that passengers on international routes arriving in Indonesia have decreased sharply from 1.5 million in December 2019, down 450 thousand to 1.15 million in January 2020. This number is also 15\% lower compared to January 2019 (Weible et al., 2020). Historically, the number of foreign tourist arrivals in February has decreased by around 200 thousand from the end of the previous year. However, in February 2020, foreign tourists drop to 500 thousand people December 2019 (Saidi, 2020). The number of foreign tourists is recorded down 29\% (y.o.y) compared to the number in February 2019 (Pristiwasa, 2020). Data from the Central Statistics Agency (BPS) as of April 1 reveals that foreign tourist arrivals through the airways decreased from 838,978 people in December 2019 to 796,934 in January 2020 and slumped again 558,892 in February 2020.

The result is in line with the decline in international flights from 1.72 million people in December 2019 to 1.68 million people in January 2020 (Alimuddin, 2020). Then, it fell again to 1.13 million people in February 2020 (OCDE, 2020). Domestic flights also decreased from 6.29 million people in January 2020. It became 5.79 million in February 2020 or decreased by $8.08 \%$, affecting the Indonesian tourism sector (OCDE, 2020). Many travel and flight companies have suffered losses due to flight stops to and from China (Saidi, 2020). Since the pandemic, the Ministry of related policies and restrictions limited China's flights to Indonesia as of February 5, 2020. Many airlines also limited their flights, such as Lion Air, which cut travel routes from Denpasar, Manado, Surabaya, Jakarta, and Batam to China, China. Even Air Asia closed all domestic flight routes until June 2020 (Pristiwasa, 2020).

Based on data by P2E LIPI, the impact (Arianti, 2017) of tourism declined on MSMEs engaged in micro food and beverage businesses reached 27\%. Meanwhile, the small and medium businesses' impact was $1.77 \%$, and the medium businesses were $0.07 \%$. The influence of coronavirus on wood and rattan handicraft business units, micro-businesses became $17.03 \%$. Small businesses in the wood and rattan handicraft sector were $1.77 \%$, and medium businesses were $0.01 \%$ (Alimuddin, 2020). Meanwhile, household consumption would also be corrected between $0.5 \%$ and $0.8 \%$. SMEs play an essential role in the structure of the Indonesian economy. Based on Bank Indonesia's data, in 2016, the MSME sector dominated $99.9 \%$ of Indonesia's business units (OCDE, 2020).

Many studies have examined the impact of tourism activities on the economy. Stynes (1999) has developed a method of analyzing the calculation of the impact of tourism activities on the economy of tourist shopping based. Basiron (2015) used an econometric approach to examine the relationship between tourism development and Bahrain's economic growth. Fandeli (2010) examined the impact of tourism activities on the Balinese economy. On the aspect of the impact of a decline in tourism activities on the economy, Suwena (2010) examined the impact of a decline in the poor's tourism activities. The global economy, world stock markets and currencies have been worst hit by lockdowns, political uncertainties and travel restrictions imposed by governments (Sikarwar, 2021).

Micro, Small and Medium Enterprises (MSMEs) have a strategic role in the Indonesian economy. Data from the Indonesian Ministry of Cooperatives and Small and Medium Enterprises in 2018 showed the number of MSME business units was $99.9 \%$ of the total business units or 62.9 million units. MSME absorbed $97 \%$ of the total employment, $89 \%$ of which was in the micro sector, and accounted for $60 \%$ of gross domestic product (Kemenkop and MSME, 2018). The COVID-19 pandemic has significantly affected the travel industry because of the subsequent travel limitations, as droop sought after among voyagers. The spread of COVID-19 has dramatically influenced the travel industry. The same number of nations have presented travel limitations trying to contain its spread. The United Nations World Tourism Organization assessed that worldwide universal vacationer appearances might diminish by 20$30 \%$ in 2020 , prompting a possible loss of US\$30-50 billion. In a significant number of the world's urban areas, arranged travel went somewhere around $80-90 \%$. Many vacation spots far and wide, for example, galleries, entertainment meccas and sports scenes are shut.

The COVID-19 pandemic situation presents challenges and opportunities for the government to maintain the existence of MSMEs. New strategy approaches for small and medium-sized enterprises (SMEs) should help increase the likelihood of overcoming the impact

5 | Muhammad Eko Atmojo' ${ }^{1}$, Helen Dian Fridayani ${ }^{2}$ 
of the pandemic since SMEs have been badly hit financially due to their limited resources and expertise (Gregurec, Furjan, \& Tomičić-pupek, 2021). The challenge is interpreted. There needs to be a short-term solution to help MSMEs and workers who are members of it. Opportunity is interpreted. Short-term solutions need to be continued with long-term solutions, mostly if related to the industrial era 4.0, which requires digital technology to support economic activity. There are several short-term solutions to maintain the existence of MSME. According to the OECD, several solutions need to be considered: stringent health protocols in carrying out economic activities by MSMEs, postponement of debit or credit payments to maintain MSME financial liquidity, financial assistance for MSMEs, and structural policies.

Since the instruction maintains social distance and echoes activities at home, the tourism sector has become sluggish. The lethargy was felt before Indonesia announced there were positive corona patients in early March 2020. Several stimuli prepared by the government to revive the tourism sector were unable to stem the negative impact of the COVID-19 corona. Many tourist attractions are closed, which means there is no income for them. Occupancy of the majority of hotels also dropped dramatically and means there is no income. In early 2020, the Indonesian government tried to boost domestic tourism by incentivizing airplane tickets to many destinations as a stimulus. The outbreak, which has spread to more than 180 countries, has significantly impacted global travel. The International Aviation Industry Association (IATA) said that the global aviation industry's loss could reach US \$ 113 billion this year due to Covid19 (Phua et al., 2020).

The Indonesian government's policy boosted local tourist visits by providing incentives through airplane ticket discounts between 30\% to $40 \%$ for ten domestic destinations from March to May 2020. The 10 intended tourist destinations include Batam, Denpasar, Yogyakarta, Labuan Bajo, Lombok, Malang, Manado, Silangit, Tanjung Pinang and Tanjung Pandan. However, the policy cannot be fully established where local tourists themselves cannot meet the occupancy rate up to $80-100 \%$ as expected by hoteliers, but hard efforts are made by the government so that there is still a movement of local tourists in various areas to be able to keep it at least there is an economic movement in the tourist areas, although not to achieve the results or occupancy rate as before the outbreak. However, the current conditions in which each region has implemented large-scale social restrictions in each region so contradict the efforts made to increase the travel rate. All ministries and other government agencies and various companies, SOEs, and the private sector have conducted meetings in the destination areas that receive incentives. The government is also currently discussing other subsidies to reduce the impact, such as taxation and debt collection relaxation for tourism industry businesses. However, this effort is still in its early stages and involves various parties, including the Ministry of Finance, OJK and banks.

Indonesia's tourism worst-hit happened in several regions or significant tourist destinations through Bali, Jakarta and Batam, Riau Islands. Bali Immigration Office notes that the number of tourists from China dropped dramatically in February. Only 4,820 tourists. In contrast to January, there were more than 113 thousand people (Ketchell, 2020). This decrease was due to the central government's policy banning trips to and from China as of February 5 , 2020. Followed also by the Capital City of Jakarta through the Central Statistics Agency or BPS DKI, Jakarta said 131,240 foreign tourists visited Jakarta in February 2020. 24.41 percent compared to January 2020 with 173,610 foreign tourists (Adit \& Pertiwi, 2020). DKI Jakarta BPS showed as many as 131,240 foreign tourists who came in February 2020. Most came from Malaysia, Japan, Singapore, South Korea, and Saudi Arabia. The details are Malaysia 15.07 percent; Japan 11.69 percent; Singapore 8.03 percent; South Korea 5.79 percent; and Saudi Arabia 5.34 percent (OCDE, 2020).

The arrival of foreign tourists was detected through two airways entrances to Jakarta, namely from Halim Perdana Kusuma Airport with 205 visits and Soekarno-Hatta Airport with 131,030 people. Compared to foreign tourist arrivals in February 2020, there was a decrease of 33.14 percent. In February 2019, the number of foreign tourists coming to Jakarta was 196,290 people. The condition was in line with the decline in occupancy rates of starred hotel rooms in Jakarta. In February 2019, the hotel occupancy rate reached 63.37 percent and fell to 54.28 
percent in February 2020. The guests staying at hotels in Jakarta, both domestic and foreign tourists, averaged over two days.

Meanwhile, the main entrance through the sea is occupied by Batam, with a total of 156,752 visits in January 2020. This number increased by 1.03 percent from January 2019, which had a total number of visits of 134,415 (Yahya, 2020). However, this number decreased significantly by 20.82 percent from 190,232 in the December 2019 period (Alimuddin, 2020). As a result, shipping from Singapore to Batam has decreased by 20 percent. The impact of the coronavirus is huge for ports in Batam.

The flow of passengers to and from Batam Center International Port dropped dramatically, especially on weekends. Typically, 10 thousand passenger flows at Batam Center Now only around 5 thousand, the volume of ship voyages from Batam Center International Port to Singapore and Malaysia, numbered 84 times (Arianti, 2017). Admittedly, the decline in the tourism sector through the number of tourist visits also occurred because those who had visited China, mostly foreign nationals, visited in the last 14 days. The prohibitions caused the number of visits to decrease, thus affecting the tourism sector.

\section{CONCLUSION}

Tourism in Indonesia becomes risky and has an impact because of dependence on tourists from China. Non-Chinese tourists are also reduced, such as Malaysia, Singapore, America, Europe, Britain and Japan. Pandemic has become a global pandemic in almost 152 countries in the world. The impact of tourism declined on MSMEs engaged in micro food and beverage businesses reached $27 \%$. Meanwhile, the small and medium businesses' impact was $1.77 \%$, and the medium businesses were $0.07 \%$. The corona virus's influence on wood and rattan handicraft business units, micro-businesses became $17.03 \%$. Small businesses in the wood and rattan handicraft sector were $1.77 \%$, and medium businesses were $0.01 \%$.

Meanwhile, household consumption will also be corrected between $0.5 \%$ and $0.8 \%$. SMEs play an essential role in the structure of the Indonesian economy. This paper cannot only focus on MSMEs' impact, especially the tourism sector, during the pandemic. Further research can be sharpened regarding the Indonesian government's policy strategies to develop pandemic era tourism.

\section{REFERENCE}

Adit, \& Pertiwi, M. A. (2020). Prioritas Kebijakan Pemerintah Indonesia dalam Menangani Pandemi Covid-19. Balairung Press. Retrieved from http://www.balairungpress.com/2020/04/prioritas-kebijakan-pemerintah-indonesiadalam-menangani-pandemi-covid-19/.https://doi.org/10.35817/jpu.v3i2.12535

Alimuddin, A. A. (2020). Dampak Virus Covid-19 terhadap sektor Pariwisata Indonesia. Sultraline. https://sultraline.id/dampak-virus-covid-19-terhadap-sektor-pariwisataindonesia/

Arianti, D. (2017). Pengaruh Sektor Pariwisata Terhadap Perekonomian dan Keruangan Kota Bukittinggi (Pendekatan Analisis Input Output). Jurnal Pembangunan Wilayah \& Kota, 12(4), 347. https://doi.org/10.14710/pwk.v12i4.13502

Chakraborty, I., \& Maity, P. (2020). COVID-19 outbreak: Migration, effects on society, global environment and prevention. Science of the Total Environment, 728, 138882. https://doi.org/10.1016/j.scitotenv.2020.138882

Gandasari, D., \& Dwidienawati, D. (2020). Content analysis of social and economic issues in Indonesia during the COVID-19 pandemic. Heliyon, 6(11), e05599. https://doi.org/10.1016/j.heliyon.2020.e05599

Gregurec, I., Furjan, M. T., \& Tomičić-pupek, K. (2021). The impact of covid-19 on sustainable 
business models in smes. Sustainability (Switzerland), 13(3), 1-24. https://doi.org/10.3390/su13031098

Hakim, L. (2021). COVID-19, tourism, and small islands in Indonesia: Protecting fragile communities in the global Coronavirus pandemic. Journal of Marine and Island Cultures, 9(1), 130-141. https://doi.org/10.21463/jmic.2020.09.1.08

Hanoatubun, S. (2020). Dampak Covid-19 Terhadap Perekonomian Indonesia. Journal of Education, Psychology and Counseling, 2(1), 146-153.

Hardilawati, W. L. (2020). Strategi Bertahan UMKM di Tengah Pandemi Covid-19. Jurnal Akuntansi \& Ekonomika, 10(1). https://doi.org/10.37859/jae.v10i1.1934

Hong, Y., Cai, G., Mo, Z., \& Gao, W., at.al. (2020). The impact of covid-19 on tourist satisfaction with b\&b in zhejiang, china: An importance- performance analysis. International Journal of Environmental Research and Public Health, 17(10), 1-20. https://doi.org/10.3390/ijerph17103747.

Isyunanda, K. P. (2020, June 15). Covidnomics: New normal? The Jakarta Post. Retrieved from https://www.thejakartapost.com/academia/2020/06/15/covidnomics-newnormal.html.

Katz, R. (2020). E conomic impact of covid-19 Report of an Economic Experts Roundtable. Imc, (July), 1-35.

Kaczmarek, T., Perez, K., Demir, E., \& Zaremba, A. (2021). How to survive a pandemic: The corporate resiliency of travel and leisure companies to the COVID-19 outbreak. Tourism $\begin{array}{llll}\text { Management, } & 84 & \text { (December } & \end{array}$ https://doi.org/10.1016/j.tourman.2020.104281

Ketchell, M. (2020, March 27). Analisis: Pemerintah masih bisa perbaiki komunikasi krisis pandemi yang sejauh ini gagal. The Conversation. Theconversation. Retrieved from https://theconversation.com/analisis-pemerintah-masih-bisa-perbaiki-komunikasikrisis-pandemi-yang-sejauh-ini-gagal-134542.

Mahadiansar, \& Aspariyana. (2020). PEST Analysis Model dalam Pengembangan Potensi Wisata Pulau Benan, Kabupaten Lingga, Kepulauan Riau. Indonesian Journal of Tourism and Leisure, 1(1). https://doi.org/10.36256/ijtl.v1i1.93.

Moreno-Luna, L., Robina-Ramírez, R., Sánchez, M. S.-O., \& Castro-Serrano, J. (2021). Tourism and Sustainability in Times of COVID-19: The Case of Spain. International Journal of $\begin{array}{lllll}\text { Environmental Research and Public Health, 18(4), } 1859 . & \end{array}$ https://doi.org/10.3390/ijerph18041859

Mustaqim, A. (2020, May 7). Ekonomi DIY Merosot di Tengah Pandemi Korona. Medcom.Id. https://www.medcom.id/ekonomi/makro/ybDlDyAb-ekonomi-diy-merosot-di-tengahpandemi-korona

OCDE. (2020). Tourism Policy Responses. degruyter (6), 1-50. https://doi.org/10.21832/9781845417338-004

Phua, J., Weng, L., Ling, L., Egi, M., Lim, C., Divatia, J. V., ... Ng, J. (2020). Review Intensive care management of coronavirus disease 2019 ( COVID-19): challenges and recommendations. The Lancet Respiratory, 8(5), 506-517. https://doi.org/10.1016/S2213-2600(20)301612. 
Pristiwasa, I. W. (2020, April). Dampak Covid-19 Terhadap Sektor Pariwisata. Minangkabaunews.

Rifa, B. (2013). Efektivitas Pemberdayaan Usaha Mikro Kecil dan Menengah ( UMKM ) Krupuk Ikan dalam Program Pengembangan Labsite Pemberdayaan Masyarakat Desa Kedung Rejo Kecamatan Jabon Kabupaten Sidoarjo. Jurnal Kebijakan Dan Manajemen Publik, 1(1).

Rukmana, A. Y., \& Sukanta, T. A. (2020). Analisis Strategi Bersaing dan Strategi Bertahan pada Industri Mikro dan Kecil Panganan Keripik Kemasan di Kecamatan Coblong Kota Bandung Jawa Barat Tahun 2020 Ditengah Situasi Sulit Penyebaran Pandemi COVID-19. JSMA (Jurnal Sains Manajemen \& Akuntansi), 12(1), 37-53. https://doi.org/10.37151/jsma.v12i1.48

Said, M. R. R. (2020). Jaminan Hak Bekerja bagi UMKM Di Tengah Masa PSBB Pada Wilayah DKI Jakarta. Adalah Buletin Hukum \& Keadilan, 4(1), 107-114.

Saidi, R. A. (2020). Dampak Pandemi Covid-19 terhadap Sektor Pariwisata. Utu.Ac.Id. http://repository.unair.ac.id/id/eprint/101898

Salim, A. (2006). Teori dan Paradigma Penelitian Sosial. Yogyakarta: Taira Wacana. https://www.tiarawacana.co.id/

Sikarwar, E. (2021). Time-varying foreign currency risk of world tourism industry: effects of COVID-19. Current Issues in Tourism, $0(0)$, 1-5. https://doi.org/10.1080/13683500.2020.1868413

Škare, M., Soriano, D. R., \& Porada-Rochoń, M. (2021). Impact of COVID-19 on the travel and tourism industry. Technological Forecasting and Social Change, 163(April 2020). https://doi.org/10.1016/j.techfore.2020.120469

Smart, K., Ma, E., Qu, H., \& Ding, L. (2021). COVID-19 impacts, coping strategies, and management reflection: A lodging industry case. International Journal of Hospitality Management, 94(June 2020), 102859. https://doi.org/10.1016/j.ijhm.2021.102859

Soehardi, S., \& Untari, D. T. (2020). The Effect of Covid-19 Pandemic on Hotel Employees, Hotel Occopancy Rates and Hotel Tax Income in Jakarta, Indonesia. Systematic Reviews in Pharmacy, 11(12), 964-972. https://doi.org/10.31838/srp.2020.5.138

Sugihamretha, I. D. G. (2020). Respon Kebijakan: Mitigasi Dampak Wabah Covid-19 Pada Sektor Pariwisata. The Indonesian Journal of Development Planning, IV(2), 191-206. https://doi.org/10.36574/jpp.v4i2.113

Weible, C. M., Nohrstedt, D., Cairney, P., Carter, D. P., Crow, D. A., Durnová, A. P., ... Stone, D. (2020). COVID-19 and the policy sciences: initial reactions and perspectives. Policy Sciences, 53(2), 225-241. https://doi.org/10.1007/s11077-020-09381-4

WHO. (2020). Operational Planning Guidelines To Support Country Preparedness And Response. USA. https://www.who.int/publications/i/item/draft-operational-planningguidance-for-un-country-teams

Yahya, A. N. (2020). Sebaran Lengkap Kasus Covid-19 Meninggal di Indonesia hingga 27 April. Retrieved from https://nasional.kompas.com/read/2020/04/28/04040061/sebaranlengkap-kasus-covid-19-meninggal-di-indonesia-hingga-27-april. 